Int. J. Morphol.,

34(4):1461-1464, 2016

\title{
Sexual Dimorphism in Histological Structure of Normal Rat Stomach
}

\author{
Dimorfismo Sexual en la Estructura Histológica del Estómago Normal de la Rata
}

\author{
Lei Zhu",*** Jian Lin Wang**
}

\begin{abstract}
ZHU, L. \& WANG, J. L. Sexual dimorphism in histological structure of normal rat stomach. Int. J. Morphol., 34(4):1461-1464, 2016.
SUMMARY: Fifty male and fifty female Spargue-Dawley rats were randomly chosen and used to study the sexual dimorphisms of stomachic histological structures. The rat stomach consisted of the nonglandular part and the glandular part. The gender differences of the nonglandular part existed in the thicknesses of the stratified squamous epithelium and the longitudinal muscle. These findings revealed that the male rat stomach may storage more foods than the female. The gastric glands occupied all the lamina propria in the glandular part. The thicknesses of the gastric glands of the female and male rat were 525.0 $\pm 95.9 \mu \mathrm{m}$ and $472.0 \pm 158.7 \mu \mathrm{m}$ respectively, and the difference was very significant $(\mathrm{p}<0.01)$. The gastric glands could be divided to two layers in the HE stain, i.e. the luminal and the basal layers. The thicknesses of the luminal layer of the female and male rat were $289.7 \pm 95.9 \mu \mathrm{m}$ and $300.0 \pm 120.7 \mu \mathrm{m}$ respectively, and the difference was insignificant $(\mathrm{p}>0.05)$. On the contrary, the thicknesses of the basal layer and the three muscle layers in the female glandular part were all thicker than those in male, and the differences were very significant $(\mathrm{P}<0.01)$. These findings indicated that the female rat stomachs may have a more powerful digestive ability than the male ones. The nucleus-glandular index of the gastric gland of the normal female and male rat were $0.19 \pm 0.05$ and $0.18 \pm 0.04$ respectively, and the difference was insignificant ( $\mathrm{p}>0.05$ ).
\end{abstract}

KEY WORDS: Rat; Stomach; Gastric glands; Nucleus-glandular index.

\section{INTRODUCTION}

Gastric cancer is the most common malignant tumor in the alimentary canal. It is well known that gastric cancer is highly prevalent and has a high mortality in some areas of the world (Jiang et al., 2009). There is a high incidence of gastric cancer in China, especially in the northwest region. The 50-80 years old people accounted for $2 / 3$ of the persons who suffered from gastric cancer, and the male and female ratio of occurrence was $2-4.1$ (Zhou et al., 1997). Yang et al. (2006) reported that thousands of genes showed sexual dimorphism in liver, adipose, and muscle, and hundreds of genes were sexually dimorphic in brain. Cardy (1991) stated that the gender differences of the normal rat mammary gland were very noticeable. While the reports about sexual dimorphism of the rat stomachic histological structure were scarce. This study is aim to provide a morphological basis for the study of sexual dimorphisms of stomach, which may help to reveal the reason why a higher incidence of gastric cancer exists in the male than female.

\section{MATERIAL AND METHOD}

Fifty male and fifty female Sprague-Dawley rats, weighing 200-250 g, 16 weeks of age, were randomly chosen and used in this study. This study was approved by The Animal Experimentation Ethics Committee of Qujing Normal University. The animals were checked for their health status before being euthanized with ethyl ether. The rat stomach was a large, crescent-shaped sac, and was divided into 2 parts: the left (nonglandular) part and the right part (glandular) part. For each animal, specimens were taken from greater curvature, lesser curvature and lateral wall of the left and right part of the stomach. For the histological study, fragments of the stomach were immersed in neutral formalin for $24 \mathrm{~h}$ and then submitted to the dehydration process with alcohol and embedded in paraffin wax. Serial sections, 5 - $6 \mu \mathrm{m}$ in thickness, were cut. After being deparaffinized, the sections were stained with hematoxylin-eosin (H\&E).

The wall of the left nonglandular part of the stomach

\footnotetext{
* Key Laboratory of Yunnan Province, Universities of the Diversity and Ecological Adaptive Evolution for Animals and Plants on YunGui Plateau, College of Biology and Environmental Science, QuJing Normal University, QuJing, Yunnan, P. R. China.

** Institute of Zoology, School of Life Sciences, Lanzhou University, Lanzhou, Gansu 730000, P.R. China.
} 
consisted of three tunics: a mucous membrane (tunica тисоsa gastris), a muscular layer (tunica muscularis gastris) and the serosa (tunica serosa gastris). The thicknesses of the mucous membrane, lamina muscularis mucosae, circular muscle and longitudinal muscle were measured at a magnification of 100 . The glandular part had the gastric glands, which could be divided to two layers in the HE stain: the luminal layer stained red as the acidophilic parietal cells were predominant, and the basal layer stained blue as the basophilic chief cells were predominant. As a result, the thicknesses of the gastric glands, the luminal layer, the basal layer, circular muscle and longitudinal muscle were also measured at a magnification of 100. In addition, in every 2000 square microns, the Nucleus-glandular index (NGI) were measured at a magnification of 1000. Nucleus-glandular index $=$ the nuclear total area in measurement range the glandular total area in measurement range. Every kind of measurements was made at five representative different points in every section. The data measured by using the MOTIC Images Advanced 3.0 software. The results were expressed as mean \pm SEM, Student's $t$ test was used for comparison of the data between two groups. Differences below the $0.05(\mathrm{P}<0.05)$ were considered significant. Differences below the $0.01(\mathrm{P}<0.01)$ were considered very significant.

\section{RESULTS AND DISCUSSION}

Like in other rodents (Perrin \& Curtis, 1980; Ghoshal unilocular hemiglandular stomach. The nonglandular part of the stomach was lined by keratinized, stratified squamous epithelium (Fig.1A). The thicknesses of the epithelium of the female and male rat were $36.9 \pm 15.5 \mu \mathrm{m}$ and $42.8 \pm 13.5 \mu \mathrm{m}$ respectively (Table I), and the difference was significant $(\mathrm{p}<0.05)$. The degree of keratinization increased near the junction between the nonglandular and glandular stomach (Fig.1B), and this was in consistent with the finding of Perrin $\&$ Curtis. The lamina muscularis mucosae was developed, and the thicknesses of those in the female and male rat were $39.5 \pm 23.9 \mu \mathrm{m}$ and $37.7 \pm 16.3 \mu \mathrm{m}$, respectively. The tunica muscularis was constituted by a thick inner layer of circular muscle and an outer layer of longitudinal muscle. The thicknesses of the longitudinal muscle of the female and male rat were $43.9 \pm 25.8 \mu \mathrm{m}$ and $83.7 \pm 59.0 \mu \mathrm{m}$ respectively, and \& Bal, 1989; Yue et al., 2010), the SD rat possessed a typical

the differences were significant $(\mathrm{P}<0.05)$. The thicker longitudinal muscle revealed that the male stomachs may storage more foods than the female ones. On the other hand, the developed muscle may help churn the foods, and the opportunity of foods contacted with the epithelium increased, which could result in the thicker epithelium. This was in consistent with the findings of Ghoshal \& Bal who assumed that the nonglandular part assisted mechanically in the digestion of food and the findings of Perrin \& Curtis who stated that the increased area of cornified epithelium may simply be an adaptation for temporary food storage.

The glandular part of the stomach was lined by simple columnar epithelium. The gastric glands occupied all the lamina propria and consisted of mucous neck cells, parietal cells and chief cells. The localization of these three kinds of cells varied between species (Ghoshal \& Bal). The thicknesses of the gastric glands of the female and male rat were 525.0 \pm 95.9 $\mu \mathrm{m}$ and $472.0 \pm 158.7 \mu \mathrm{m}$ respectively (Table II), and the difference was very significant $(\mathrm{p}<0.01)$. The gastric glands were organized into two distinct layers (Fig. 1C), which was in consistent with the finding of Ofusori \& Caxton-Martins (2008) in the stomach of bat. In the luminal layer, the parietal cells lined the gastric pits were predominant, intermingling with the mucous neck cells. The thicknesses of the luminal layer of the female and male rat were $289.7 \pm 95.9 \mu \mathrm{m}$ and $300.0 \pm 120.7 \mu \mathrm{m}$ respectively, and the difference was insignificant ( $p>0.05)$. The parietal cells were responsible for HCL secretion. Ofusori \& Caxton-Martins stated that the parietal cells play a single role of maintaining a low $\mathrm{PH}$ needed for the digestive enzymes to function, although the destinies of the parietal cells in different animals were significantly different. The basophilic chief cells were predominately occupied the basal layer, intermingling with the acidophilic parietal cells (Fig. 1D). The thicknesses of the basal layer of the female and male rat were $217.3 \pm 49.1 \mu \mathrm{m}$ and $167.1 \pm 51.5$ $\mu \mathrm{m}$ respectively, and the difference was very significant $(\mathrm{p}<0.01)$. The basal layer accounted for $35-41 \%$ of the gastric glands, which was similar to the finding of Ghoshal \& Bal. The chief cells were mostly responsible for secreted the pepsinogen. Ofusori \& Caxton-Martins disclosed that the different zymogenic cell densities accounted for the ingested foods of different protein and fat. As the food qualities of the female and male rat were same in the laboratory, this reveal that the female rat stomach may have a more strong ability to digest the protein than the male one. The lamina muscularis Table I Measurements of the nonglandular part of the adult male and female rat $(\mu \mathrm{m})$.

\begin{tabular}{lcc}
\hline Measurements & Female & Male \\
\hline The thickness of the stratifie d squamous epithelium & $36.9 \pm 15.5^{*}$ & $42.8 \pm 13.5^{*}$ \\
The thickness of the lamina muscular is muscosae & $39.5 \pm 23.9$ & $37.7 \pm 16.3$ \\
The thickness of the circular muscle & $135.2 \pm 82.7$ & $140.8 \pm 59.4$ \\
The thickness of the longitudinal muscle & $43.9 \pm 25.8^{* *}$ & $83.7 \pm 59.0^{* *}$ \\
\hline
\end{tabular}

*Significant at $\mathrm{P}<0.05 * *$ Significant at $\mathrm{P}<0.01$

1462 mucosae constituted by a layer of circular smooth muscle. The tela submucosa consisted of loose fibrous, connective tissue with blood vessels. The tunica muscularis constituted by a thick inner circular muscle layer and a relatively thin 

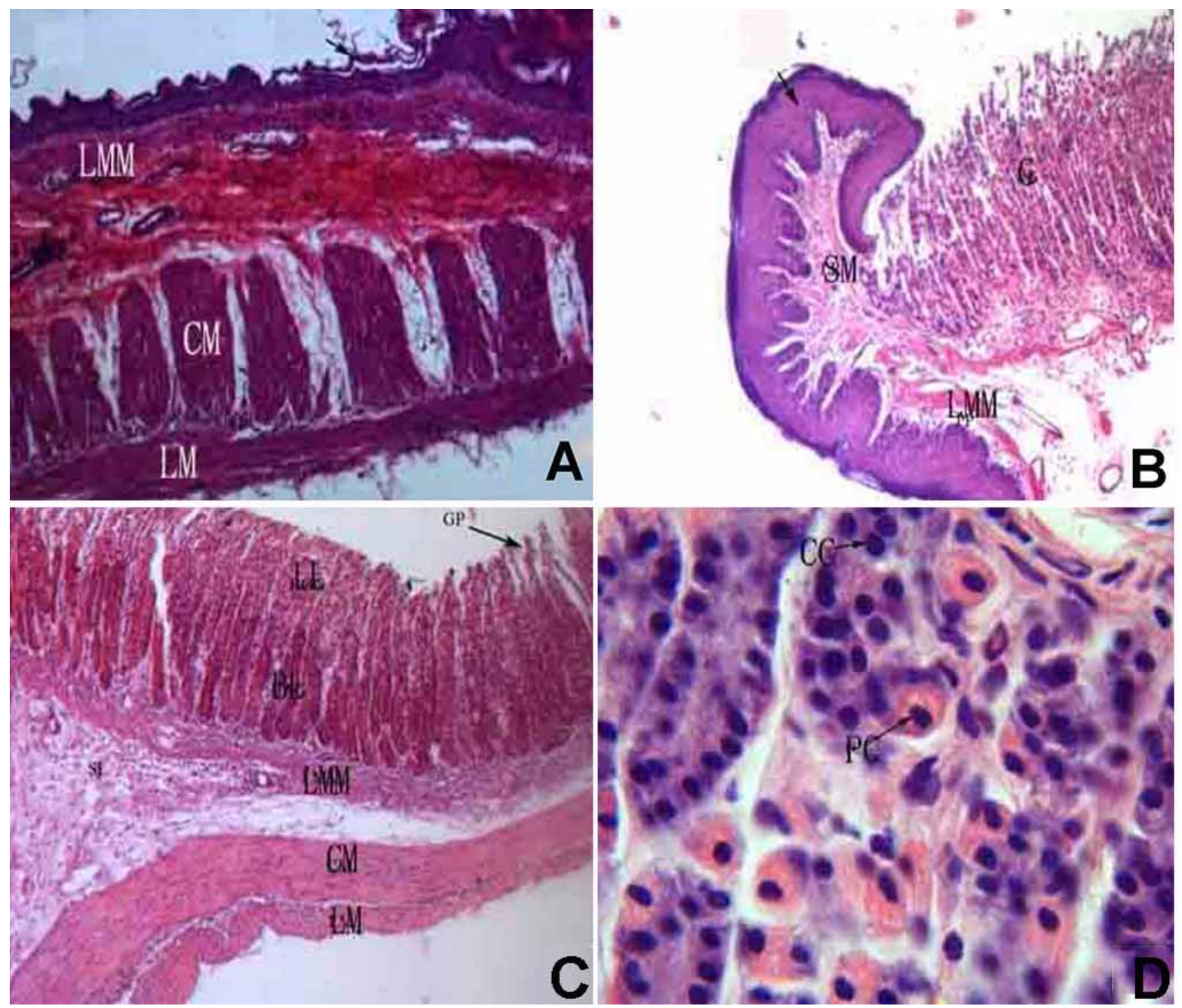

Fig. 1. The histological structures of the rat stomach. A. In the nonglandular part, the stratified squamous epithelium (arrow) was cornified and the circular muscle (CM) was developed. H.E. x100. B. Near the junction of the nonglandular part and glandular part, the stratified squamous epithelium (arrow) gradually thickened and the gastric glands (G) abruptly appeared. H.E. x100. C. In the glandular part. The gastric glands could be divided to two layers in the HE stain, i.e. the luminal (LL) and basal (BL) layers. HE x100. D. The basal layer of the glandular part was predominantly occupied by the chief cells (CC), intermingling with a few parietal cells (PC). H.E. x1000. SM, submucous layer; LM, longitudinal muscle; CM, circular muscle; LMM, lamina muscularis muscosae; GP, gastric pits.

Table II. Measurements of the glandular part of the adult male and female rat $(\mu \mathrm{m})$.

\begin{tabular}{lll}
\hline Measurements & Female & \multicolumn{1}{c}{ Male } \\
\hline The thickness of the gastric glands & $525.0 \pm 118.9^{* *}$ & $472.0 \pm 158.7^{* *}$ \\
The thickness of the luminal layer of the glands & $289.7 \pm 95.9$ & $300.0 \pm 120.7$ \\
The thickness of the basal layer of glands & $217.3 \pm 49.1^{* *}$ & $167.1 \pm 51.5^{* *}$ \\
The thickness of the lamina muscularis muscosae & $32.0 \pm 12.8^{* *}$ & $24.1 \pm 11.0^{* *}$ \\
The thickness of the circular muscle & $109.5 \pm 48.2^{* *}$ & $94.3 \pm 52.1^{* *}$ \\
The thickness of the longitudinal muscle & $37.9 \pm 20.4^{* *}$ & $31.4 \pm 15.2^{* *}$ \\
\hline
\end{tabular}

** Significant at $\mathrm{P}<0.01$

outer longitudinal layer. The lamina muscularis muscosae, the circular muscle and longitudinal muscle of female stomach were all thicker than those of male $(\mathrm{P}<0.01)$. The tensile strength of female stomachic muscle may be stronger and made the foods easier to digest than in the male stomach (Ofusori \& Caxton-Martins). What's more, the peptic would decrease when people suffered from the chronic gastritis, gastrectasis or other stomachic disease (Zhou et al.). As a result, the same damage may result in more serious consequence in the male's stomach than in that of female because of the thinner basal layer of the 
zymogenic cells. On the other hand, the wall of female rat stomach was thicker than that of male, which may inhibit the lesions infiltrate to the submucous layer and destructed the vascular network, then result in the necrosis of surface tissue. Ghoshal \& Bal stated that the thickness of the tunica muscularis decreased gradually from the nonglandular to the glandular part of the stomach. This finding was also confirmed by the present study.

The nucleus-glandular index of the gastric gland of the normal female and male rat were $0.19 \pm 0.05$ and $0.18 \pm 0.04$ respectively, and the difference was insignificant $(\mathrm{p}>0.05)$. In glandular organ tumor, the degree of the nucleosis could be revealed by the nucleus-glandular index. The densities of the chief cells and the parietal cells were variable in the different layers, consequently, measuring the nucleus-glandular index in all the gland or a fixed measured area may be more accurate and easy to handling than measuring the cellar destinies of glands in random (Ofusori \& Caxton-Martins). It is needed further study if these indexes had same changes when the rat was infected by helicobacter pylori or had other stomachic diseases.

In conclusion, there were sexual dimorphisms in the histological structure of the normal rat stomach. To study the structural difference of the stomach between the sexes may elucidate that the male has a higher incidence of gastric cancer and it is beneficial to use drug according to the sex in the future.

\section{ACKNOWLEDGMENTS}

The study was supported by Scientific Foundation of Qujing Normal University (2009ZD005) and the National Natural Science Foundation of China (31260087 to L-Z Tang). I am grateful to Key Subject of Ecology and Animal Sience Teaching Team in QuJing Normal University, Assistant for their technical help.

ZHU, L. \& WANG, J. L. Dimorfismo sexual en la estructura histológica del estómago normal de la rata. Int. J. Morphol., 34(4):1461-1464, 2016.

RESUMEN: Se seleccionaron al azar 100 ratas SpragueDawley, 50 de sexo masculino y 50 de sexo femenino, para estudiar los dimorfismos sexuales de las estructuras histológicas del estómago. El estómago de la rata consiste de una parte no glandular y de una parte glandular. Existen diferencias de género en la parte no glandular en relación al espesor del epitelio escamoso estratificado y del músculo longitudinal. Estos hallazgos revelaron que el estómago de las ratas masculinas puede almacenar más alimentos que las hembras. Las glándulas gástricas ocuparon toda la lámina propia de la parte glandular. Los espesores de las glándulas gástricas de la rata hembra y macho fueron $525,0 \pm 95,9 \mathrm{~mm}$ y $472,0 \pm 158,7 \mathrm{~mm}$, respectivamen- te, y la diferencia fue muy significativa $(\mathrm{p}<0,01)$. En la tinción de Hematoxilina-Eosina (H-E) se visualiza la división de las glándulas gástricas en dos capas, es decir, en las capas luminal y basal. Los espesores de la capa luminal de la rata hembra y macho fueron $289,7 \pm 95,9 \mathrm{~mm}$ y $300,0 \pm 120,7 \mathrm{~mm}$, respectivamente, y la diferencia fue no significativa $(p>0,05)$. Por el contrario, los espesores de la capa basal y las tres capas musculares en la parte glandular fueron más gruesos en las ratas hembras y las diferencias fueron muy significativas ( $\mathrm{p}<0,01$ ). Estos hallazgos indicaron que los estómagos femeninos de rata pueden tener una capacidad digestiva más potente que los masculinos. El índice núcleo-glandular de la glándula gástrica de la rata normal femenina y masculina fue $0,19 \pm 0,05$ y $0,18 \pm 0,04$ respectivamente, y la diferencia fue no significativa $(p>0,05)$.

PALABRAS CLAVE: Rata; Estómago; Glándulas gástricas; Núcleo-índice glandular.

\section{REFERENCES}

Cardy, R. H. Sexual dimorphism of the normal rat mammary gland. Vet. Pathol., 28(2):139-45, 1991.

Ghoshal, N. G. \& Bal, H. S. Comparative morphology of the stomach of some laboratory mammals. Lab. Anim., 23(1):21-9, 1989.

Jiang, X. Y.; Qian, L. P.; Zheng, X. J.; Xia, Y. Y.; Jiang, Y. B. \& Sun, D. Y. Interventional effect of Ginkgo biloba extract on the progression of gastric precancerous lesions in rats. J. Dig. Dis., 10(4):293-9, 2009.

Ofusori, D. A. \& Caxton-Martins, E. A. A comparative histomorphometric study of the stomach of rat (Rattus norvegicus), bat (Eidolon helvum) and pangolin (Manis tricuspis) in relation to diet. Int. J. Morphol., 26(3):669-74, 2008.

Perrin, M. R. \& Curtis, B. A. Comparative morphology of the digestive system of 19 species of Southern African myomorph rodents in relation to diet and evolution. S. Afr. J. Zool., 15(1):22-33, 1980.

Yang, X.; Schadt, E. E.; Wang, S.; Wang, H.; Arnold, A. P.; Ingram-Drake, L.; Drake, T. A. \& Lusis, A. J. Tissue-specific expression and regulation of sexually dimorphic genes in mice. Genome Res., 16(8):995-1004, 2006.

Yue, X.; Lu, J.; Wang, Z.; Feng, J.; Tong, C. \& Liu, Z. Research on Morphology and Histology of Stomach in Mandarin vole (Lasiopodomys mandarinus). Chin. J. Comp. Med., 20(5):72-4, 2010.

Zhou, J.; Chen, Y. \& Wang, L. Pathogenesis of gastric cancer. Chin. J. Gastroenterol., 5(3):180-1, 1997.

Correspondence to:

Dr. JL-Wang

Institute of Zoology

School of Life Sciences

Lanzhou University

Lanzhou, Gansu 730000

CHINA

E-mail: jlwang@|zu.edu.cn

Received: 30-11-2015

Accepted: 10-08-2016 